University of Nebraska - Lincoln

DigitalCommons@University of Nebraska - Lincoln

Faculty Publications from the Harold W. Manter Laboratory of Parasitology

2003

\title{
A NEW SPECIES OF LAELAPINE MITE (ACARI: PARASITIFORMES: LAELAPIDAE) ASSOCIATED WITH PROECHIMYS DIMIDIATUS IN THE ATLANTIC FORESTS OF BRAZIL
}

Donald Gettinger

University of Nebraska-Lincoln, donaldgettinger@gmail.com

Helena Godoy Bergallo

Universidade do Estado de Rio de Janeiro

Follow this and additional works at: https://digitalcommons.unl.edu/parasitologyfacpubs

Part of the Parasitology Commons

Gettinger, Donald and Bergallo, Helena Godoy, "A NEW SPECIES OF LAELAPINE MITE (ACARI:

PARASITIFORMES: LAELAPIDAE) ASSOCIATED WITH PROECHIMYS DIMIDIATUS IN THE ATLANTIC FORESTS OF BRAZIL" (2003). Faculty Publications from the Harold W. Manter Laboratory of Parasitology. 681.

https://digitalcommons.unl.edu/parasitologyfacpubs/681

This Article is brought to you for free and open access by the Parasitology, Harold W. Manter Laboratory of at DigitalCommons@University of Nebraska - Lincoln. It has been accepted for inclusion in Faculty Publications from the Harold W. Manter Laboratory of Parasitology by an authorized administrator of DigitalCommons@University of Nebraska - Lincoln. 


\title{
A NEW SPECIES OF LAELAPINE MITE (ACARI: PARASITIFORMES: LAELAPIDAE) ASSOCIATED WITH PROECHIMYS DIMIDIATUS IN THE ATLANTIC FORESTS OF BRAZIL
}

\author{
Donald Gettinger and Helena Godoy Bergallo* \\ Department of Biology, University of Central Arkansas, Conway, Arkansas 72035, and Harold W. Manter Laboratory of Parasitology, University \\ of Nebraska-Lincoln, Lincoln, Nebraska 68588-0514. e-mail: donaldg@alltel.net
}

\begin{abstract}
Tur megistoproctus, a new species of Laelapinae, is described from the pelage of the echimyid rodent Proechimys dimidiatus from the Atlantic forests of Ilha Grande, south of Rio de Janeiro. Measurements and illustrations are included for females and males. Another laelapine mite species, Tur turki Fonseca, co-occurred with T. megistoproctus in our studies and was recorded from the same host individuals and localities. These 2 laelapine mite species appear to be exclusively associated with a complex of echimyid rodent species (subgenus Trinomys) in the Atlantic forests of southeastern Brazil.
\end{abstract}

Laelapid mites of Tur spp. are associated with the pelage of Neotropical echimyid rodents, occurring primarily on species of the most primitive host genera, Proechimys, Mesomys, and Thrichomys. The rodent family Echimyidae is both diverse and widely distributed geographically in the neotropics and hence is poorly known taxonomically (Woods, 1993). Fifteen species of Tur are presently recognized, and these mites are distinctive components of the ectoparasite fauna infesting echimyid rodents. However, a wide range of morphological variation is represented within this genus, and more comparative studies are needed to clarify the taxonomic boundaries among these mite species.

As presently defined (Furman, 1972), Tur spp. are distinguished taxonomically by the following set of morphological characters: (1) epigynial and anal shields fused or in juxtaposition; (2) epigynial shield with 8 setae, anal shield with 3 setae; (3) genu of leg IV with 9 setae; (4) broad extension of peritremalia posterior to stigma; (5) female chelicera partially or completely enveloped in a membrane; (6) chelicerae with long pseudosetae (arthrodial processes) at the base of the moveable digit; (7) gnathosomal setae usually spiniform; (8) dorsal shield usually with 39 pairs of setae; and (9) dorsal setae robust and many ventral setae strongly spiniform, with striated appearance.

During preliminary surveys of the arthropods associated with small mammals in the Atlantic forests of eastern Brazil, we encountered a new species of Tur from the echimyid Proechimys (subgenus Trinomys) dimidiatus (Gunther, 1877) on Ilha Grande, a large island close to the mainland and south of the city of Rio de Janeiro. This new mite is quite distinct and has some characteristics that might be considered worthy of generic status, but we have chosen to formally describe it within Tur pending further comparative studies.

\section{MATERIALS AND METHODS}

Ectoparasites were sampled in the field by brushing live hosts; see Martins-Hatano et al. (2002) for detailed description of sampling methods. Representative specimens were mounted individually in Hoyer medium, ringed in Glyptal, and measured with a stage-calibrated ocular micrometer. All measurements are in micrometers $(\mu \mathrm{m})$; when referring to more than 1 specimen, measurements are given as the mean, followed by the range in parentheses. We use the system of mite setal nomenclature developed by Lindquist and Evans (1965) and follow Wilson and Reeder (1993) for mammalian taxonomy and nomenclature.

Received 7 November 2002; revised 3 February 2003; accepted 3 February 2003.

* Setor de Ecologia, Instituto de Biologia Roberto Alcântara Gomes, Universidade do Estado de Rio de Janeiro, Rua São Francisco Xavier 524, Rio de Janeiro, RJ, Brazil.

\section{DESCRIPTION}

\section{Tur megistoproctus $\mathbf{n}$. sp.}

(Figs. 1-3)

Female: Dorsal shield (Fig. 1A) ovoid oblong, broadest just anterior to midline, with 35 consistent pairs of simple setae; all setae thick, somewhat expanded at base, except for J5 and Z5, which are thin and simple; podonotal $\mathrm{j}, \mathrm{z}$, and $\mathrm{r}$ series complete; $\mathrm{s}$ series unideficient, hypotrichy of the posterior opisthonotal region; $\mathrm{J} 4, \mathrm{Z} 4$, and $\mathrm{S} 4$ absent; pores and sculpturing as shown in Figure 1. Stigma lateral with anterior peritreme reduced, extending dorsally to lie adjacent to the dorsal shield at the level of $\mathrm{j} 4$ (over anterior half of coxae II); peritrematic shield extending posterior to stigma. Unarmed dorsum without setae, except for 7 pairs of marginal spiniform setae that form the dorsal component of a series of strong spiniforms along the opisthosomatic margin; anterior pair subtend the stigma; 3 posterior pairs comparatively long and robust; terminal pair longest and strongest setae on the body.

Tritosternum with pilose laciniae. Presternal region distinctly sculptured. Sternal shield wider than long, broadest at lateral angles extending between coxae II and III; anterior margin slightly convex; posterior margin more deeply concave; surface sculptured with both reticulations and punctations; 3 pairs of strong sternal setae; 2 pairs of elongate lyriform sternal pores; third pair of tiny pores on unarmed integument medial to metasternal plates that bear a strong fourth pair of sternal setae. Epigynial shield narrow anteriorly, expanding laterally to form a deep posterior concavity, enclosing anterior part of anal shield; surface unsculptured; anterior flap with radiating lines nearly reaching to posterior margin of the sternal shield; epigynial setae inserted near margin of shield at posterior level of coxa IV; 3 pairs of accessory setae, first 2 pairs inserted medial to shield margin; third pair on margin and reaching nearly to level of paranal setae; small pair of pores on lateral margin of shield between genital setae and first pair of accessory setae. Parapodal plates posterior to coxa IV connected to medial margin of posterior peritrematic shield (unlike generic description of Furman and Tipton, 1958). Metapodal plates long and slender, with punctate surface sculpturing. Anal shield enormous, elongate ovoid; paranal setae and postanal seta blunt spiniforms of similar size; anus greatly expanded, extending two-thirds of total shield length, from near the anterior margin, to a point well beyond the level of the paranal setae; cribrum composed of 3-4 rows of teeth, extending laterally to a point anterior to insertion of postanal seta. Unarmed opisthogaster with 5 pairs of setae; 1 pair just lateral to insertion of posterior epigynial 


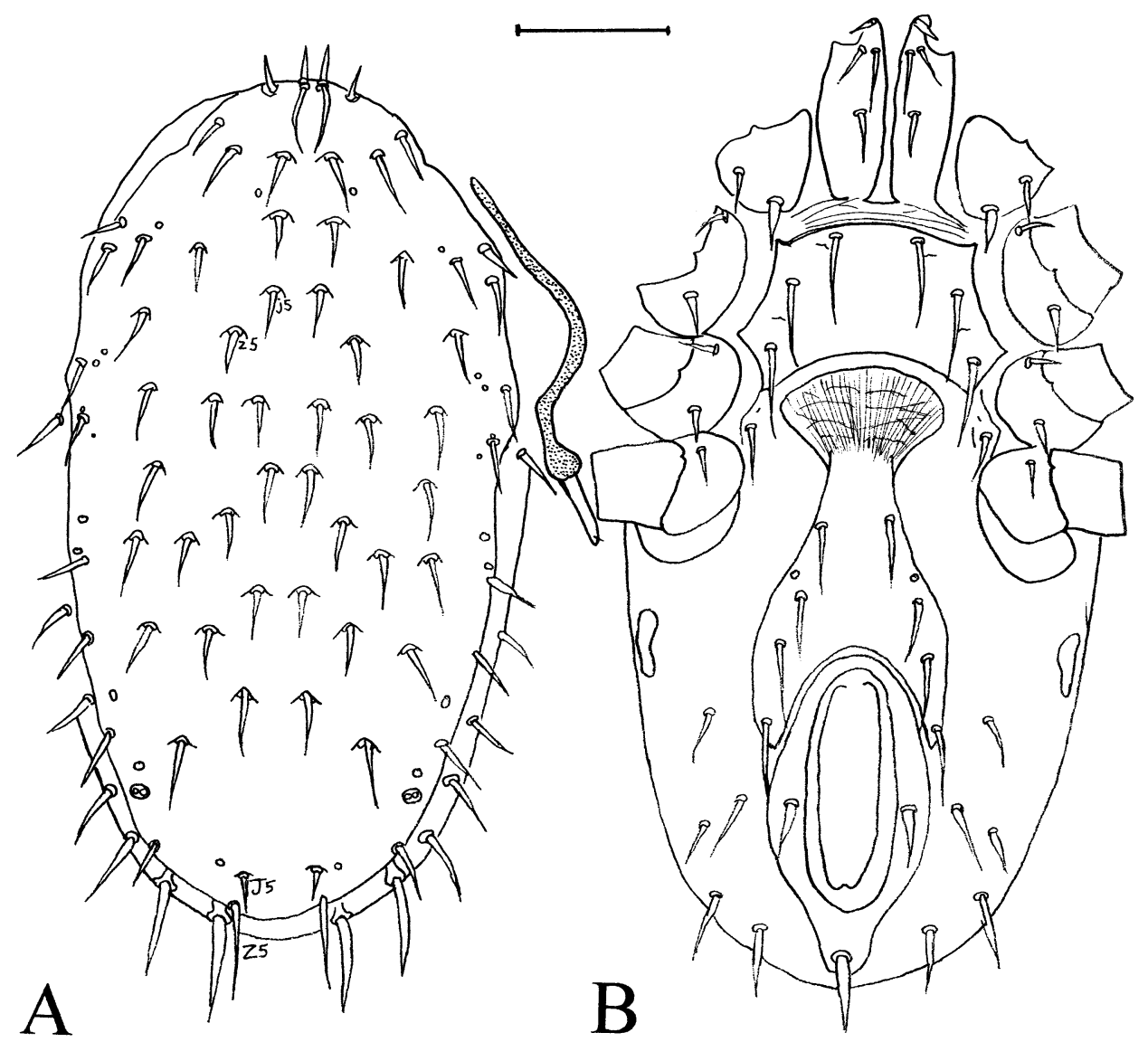

Figure 1. Tur megistoproctus, female. (A) Dorsum. (B) Venter. Bar $=100 \mu \mathrm{m}$.
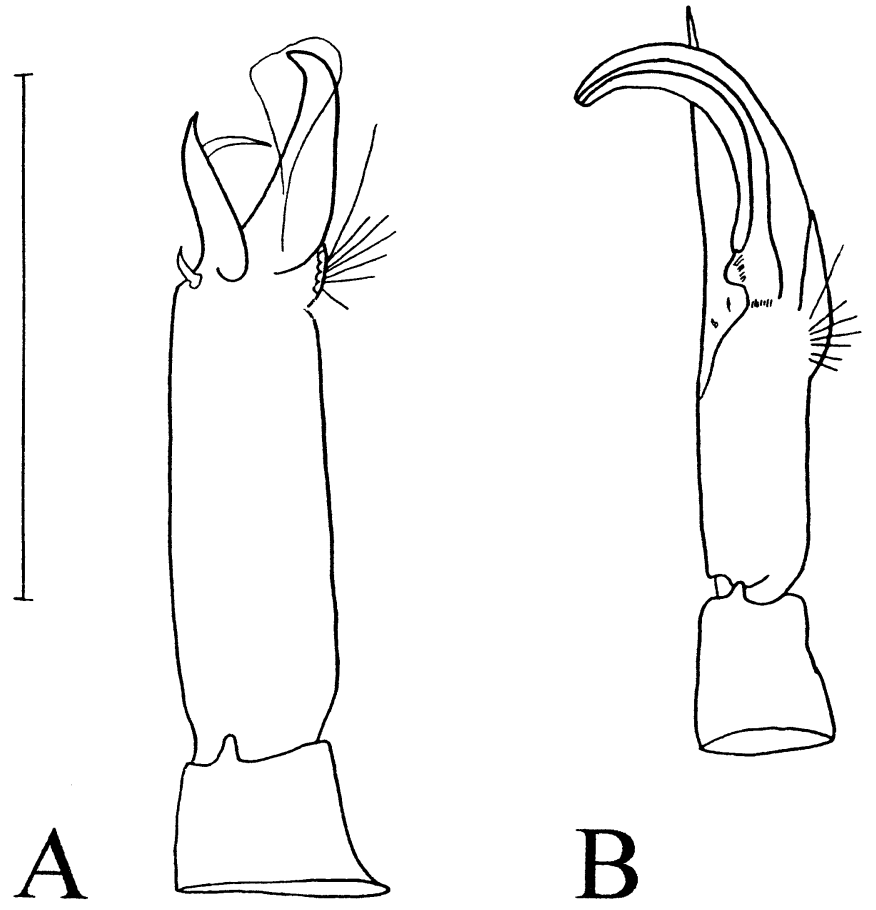

FiguRE 2. Tur megistoproctus, Chelicera: (A) female. (B) Male. Bar $=100 \mu \mathrm{m}$. accessory setae, 2 pairs at level of paranal setae, and 2 pairs near level of postanal seta.

Epistome simple, slightly bilobed. Labrum long and fimbriated, with acute tip extending to level of palpal genu. Chelicera (Fig. 2A) chelate; movable digit edentate, with strong terminal hook enclosed in membranous sheath; arthrodial processes well-developed; fixed digit shorter than movable digit, edentate, with small dorsal seta and long sickle-shaped pilus dentilis. Ventral chaetotaxy normal; gnathosomal setae strong setiforms, nearly as long as inner hypostomal setae. Palpal apotele 2pronged. Deutosternum with 6-7 rows of denticles.

Legs I and II with femur and genu crassate; legs III and IV of more uniform width; order of length from longest: IV, I, II, III. Leg I with paired claws present, but smaller than those on the other legs. Coxa I with posteroventral ridge bearing spiniform proximal seta; posterior setae of coxae II and III strong and slightly spiniform; most postcoxal setae slender but some anterior setae of trochanters III and IV spinose; dorsal setae (AD1 and PD1) at distal margin of femurs I and II enlarged slightly. Genu IV with 9 setae. Chaetotaxy nearly holotrichous for dermanyssoid-type mites, but some setae may be highly reduced or missing: $\mathrm{I}=2,6,13,13,13,-; \mathrm{II}=2,5,11,11,10,18$; $\mathrm{III}=2,5,6,9,8,18 ; \mathrm{IV}=1,5,6,9,9,18$.

Measurements based on 20 specimens: Dorsal shield length, 631 (622-640); dorsal shield width at midlevel, 312 (298-320); j5, 36 (35-38); J5, 19 (18-21); Z5, 65 (60-67); gnathosomal seta, 29 (27-30); inner hypostomal seta, 33 (31-35); sternal 


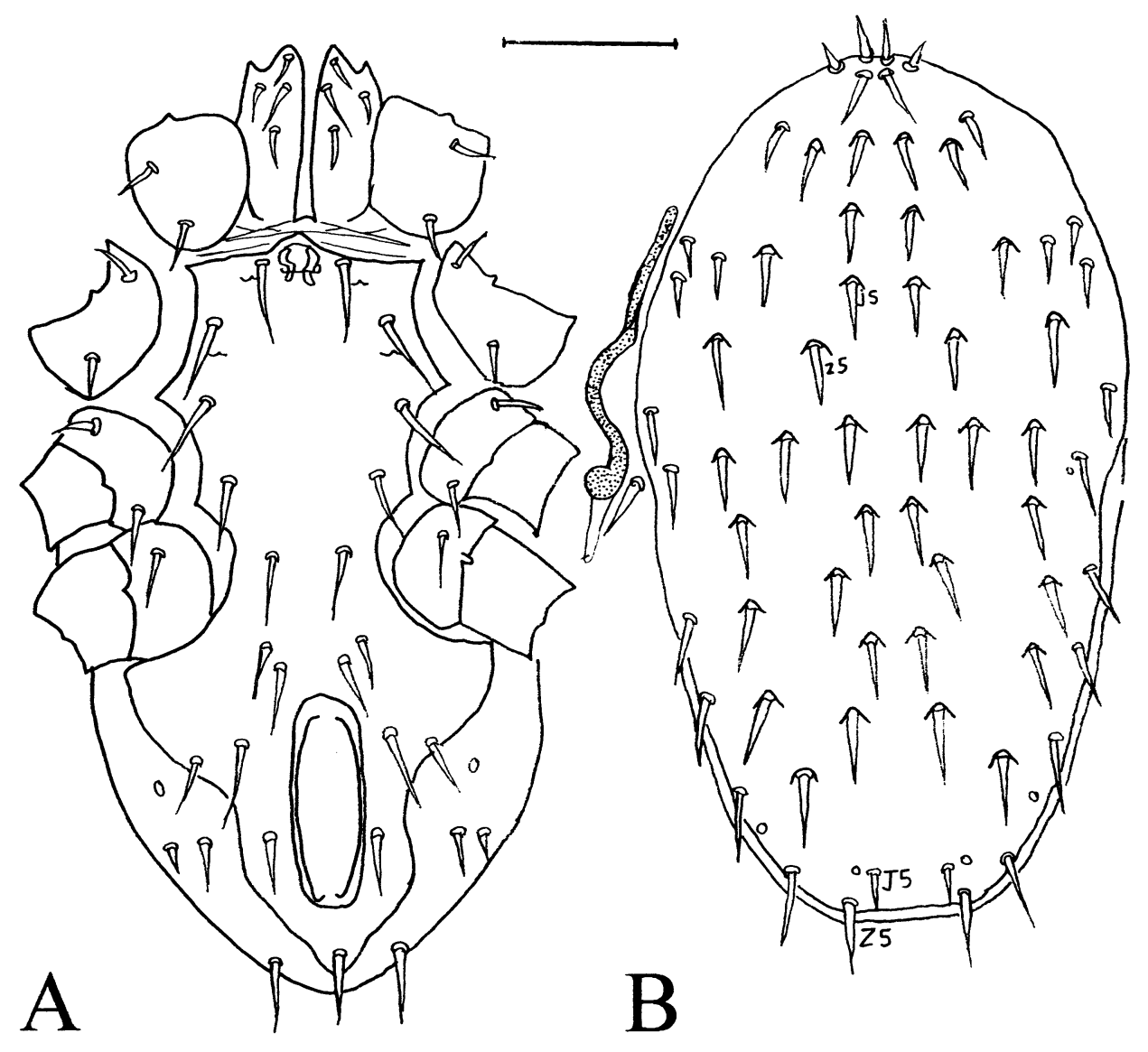

Figure 3. Tur megistoproctus, male. (A) Venter. (B) Dorsum. Bar $=100 \mu \mathrm{m}$.

shield length, 89 (85-95); sternal shield width at level of st2, 144 (140-151); st1, 60 (57-63); st3, 67 (62-70); epigynial shield length 104 (100-109); epigynial shield greatest width, 140 (133-146); st4, 61 (55-63); st5, 55 (52-58); anal shield length, 229 (220-237); anal shield width, 119 (115-124); coxa I, proximal seta, 26 (25-28); coxa II, posterior seta, 29 (2732); coxa III, posterior seta, 25 (23-27); coxa IV, seta, 20 (1921); longest anterior dorsal seta on femur I, 43 (41-44).

Male: Dorsal shield (Fig. 3B) entire, narrowing abruptly just posterior to level of podosoma; greatest width of shield at level of $\mathrm{j} 5 / \mathrm{z} 6 ; 32$ consistent pairs of simple setae; $\mathrm{j} / \mathrm{J}$ series complete; $\mathrm{Z}$ series incomplete, but $\mathrm{Z}$ series complete; $\mathrm{J} 5$ less than half the length of $\mathrm{Z5}$; Z5 longer than strong setae of terminal opisthosomal margin. All setae on dorsal shield similar in size to female, but unarmed dorsum without posterior marginal row of spiniforms; only seta subtending stigma present in male.

Tritosternum with lightly fimbriate laciniae. Holoventral shield (Fig. 3A) wide, reaching coxal margins anteriorly; expanded laterally posterior to legs to mid-length of trochanter IV; presternal genital opening; 5 primary setal pairs present on sternogenital region, followed by 2 central setal pairs anterior to anus and 2 pairs setae lateral to anus; adanal setae nearly as long as the postanal seta; cribrum as in female. Unarmed opisthogaster with 2 pairs setae at level of paranals and 1 pair at level of postanal seta. Metapodal shields are present but greatly reduced. Peritremes extended posterior to stigma and anterior to a point level with anterior margin of coxa II.
Gnathosomatic characters as in female. Chelicera (Fig. 2B) with long arthrodial processes; fixed digit elongate and membranous, nearly as long as spermatodactyl; pilus dentilis and dorsal seta greatly reduced or absent. Spermatodactyl fused with the movable digit, broad and curved ventrally to nearly a right angle; entire process tapering to a blunt tip.

Leg proportions and chaetotaxy as in female, but spiniform setae reduced to strong setiforms.

Measurements based on 10 specimens: Dorsal shield length, 485 (474-492); dorsal shield width at midlevel, 265 (255-270); j5, 34 (32-36); J5, 21 (17-22); Z5, 57 (53-63); gnathosomal seta, 23 (22-25); inner hypostomal seta, 24 (23-25); st1, 50 (49-50); st3, 54 (52-56); st4, 48 (46-50); st5, 43 (40-46); paranal seta, 33 (32-34); postanal seta, 41 (40-43); coxa I, proximal seta, 26 (25-28); coxa II, posterior seta, 27 (25-28); coxa III, posterior seta, 24 (22-25); coxa IV, posterior seta, 21 (2023); longest anterior dorsal seta on femur I, 33 (31-35).

\section{Taxonomic summary}

Type host: Proechimys dimidiatus (Günther, 1877). Host voucher specimens of $P$. dimidiatus collected from the type locality were deposited in the vertebrate collection at the Museu Nacional in Rio de Janeiro, but the acarological material examined and described were collected from host animals that were sampled as part of a mark-recapture study and were released back into the field. 
Locality: Ilha Grande, Vila Dois Rios, $23^{\circ} 05^{\prime}-23^{\circ} 15^{\prime} \mathrm{S}$, $44^{\circ} 06^{\prime}-44^{\circ} 23^{\prime} \mathrm{W}$; municipality of Angra dos Reis, Rio de Janeiro State, Brazil.

Specimens deposited: Holotype, allotype, and a series of paratypes at the Instituto Butantan, São Paulo, Brazil; a series of paratypes at the Harold W. Manter Laboratory of Parasitology, University of Nebraska-Lincoln, Lincoln, Nebraska, U.S.A.

Etymology: The specific epithet of $T$. megistoproctus was taken from megisto (Greek), the largest, and proctus (Greek), anus.

\section{Remarks}

Thirty females and 10 males were examined and measured as follows: Holotype female ex $P$. dimidiatus \#14, Vila Dois Rios, Ilha Grande, Rio de Janeiro, Brazil, captured and brushed on 31 January 1998. Allotype male collected from the same host individual and date as the holotype female. Paratypes: 9 females and 3 males collected from the type host, $P$. dimidiatus $\# 14$, at the same locality and date as the holotype female and allotype male; 4 females, 1 male, ex $P$. dimidiatus \#5, from the type locality on October 5 1997; 7 females, 2 males ex. Proechimys dimidiatus \#16, from the type locality on January 7 1998; 3 females, 3 males ex Proechimys dimidiatus \#35, from the type locality on October 3 1997; 6 females ex Proechimys dimidiatus \#18, from the type locality on January 71998.

Two species of Tur are common associates of $P$. dimidiatus on Ilha Grande, i.e., T. turki Fonseca, and the new species, $T$. megistoproctus. Fonseca (1957-1958) described T. turki from a series of mites collected by the National Plague Service in the states of Bahia and Maranhão; he reported the holotype from Proechimys iheringi, and paratypes from Proechimys albispinus. However, both these hosts are sister species of the type host, and they are all classified within the subgenus Trinomys. We also have specimens of both $T$. turki and T. megistoproctus from Proechimys (Trinomys) iheringi collected from mainland localities in the states of Rio de Janeiro and Sao Paulo. Apparently these 2 nominal mite species are associated exclusively with a closely related group of echimyids (subgenus Trinomys) in the Atlantic forests of eastern Brazil. MartinsHatano et al., (2002) provided host-mite population indices and noted important differences in the age and sexual structure of laelapine mite populations infesting rodents and marsupials on Ilha Grande. When laelapines are collected from the skin and pelage of neotropical mammals, mite populations are usually highly biased toward the female stage (Gettinger, 1987, 1992) but $P$. dimidiatus on Ilha Grande is also infested by high numbers of males and nymphs of both $T$. turki and T. megistoproctus. All developmental stages of $T$. megistoproctus are easily distinguished from other known species of genus by distinctive genital shield and greatly expanded anal shield and anus. Also, with females and males, general shape of idiosoma is distinctive; much longer than broad. It is easy to separate $T$. megistoproctus from other congeneric mite species (T. turki) associated with hosts of the subgenus Trinomys. Future studies should discern whether this is a general characteristic of Tur populations infesting neotropical echimyid rodents.

\section{ACKNOWLEDGMENTS}

We thank C. F. D. Rocha, M. A. S. Alves, M. Van Sluys, Fernanda Martins-Hatano, David Bossi, and Emerson Bittencourt for their help with this project. We also thank G. W. Krantz and F. J. Radovsky for deterring us from using the specific epithet "grandibunda," and putting us on a more formal etymological course. We also thank the coordinators of CEADS/UERJ, C. F. D. Rocha and J. C. Dansinger, for logistical support. This project was carried out while the senior author was visiting the Universidade do Estado do Rio de Janeiro as a Fulbright Scholar.

\section{LITERATURE CITED}

FonSECA, F. 1957-1958. Notas de Acarologia XLIV. Inquerito sobre a fauna a acarologica de parasitas no nordeste do Brasil. Memorias do Instituto Butantan 28: 99-186.

FuRMAN, D. P. 1972. Laelapid mites (Laelapidae: Laelapinae) of Venezuela. Brigham Young University Science Bulletin, Biological Series 17: 1-58.

— AND V. J. TIPTON. 1958. Tur uniscutatus (Turk) 1946 (Acarina: Laelaptidae) from neotropical rodents. Journal of Parasitology 44: 541-547.

GeTtingER, D. 1987. Host associations of Gigantolaelaps (Acari: Laelapidae) in the Cerrado Province of Central Brazil. Journal of Medical Entomology 24: 559-565.

. 1992. Host specificity of Laelaps (Acari: Laelapidae) in Central Brazil. Journal of Medical Entomology 29: 827-833.

LindQuist, E. E., AND G. O. Evans. 1965. Taxonomic concepts in the Ascidae, with a modified setal nomenclature for the idiosoma of the Gamasina (Acarina: Mesostigmata). Memoirs of the Entomological Society of Canada 47: 1-64.

Martins-Hatano, F., D. Gettinger, and H. G. Bergallo. 2002. Ecology and host specificity of laelapine mites (Acari: Laelapidae) of small mammals in an Atlantic forest area of Brazil. Journal of Parasitology 88: 36-40.

Wilson, D. E., AND D. M. REEDER. 1993. Mammal species of the world: A taxonomic and geographic reference. Smithsonian Institute, Washington, D.C., 1,207 p.

Woods, C. A. 1993. Suborder Hystricognathi. In Mammal species of the world: A taxonomic and geographic reference, D. E. Wilson and D. M. Reeder (eds.). Smithsonian Institute, Washington, D.C., p. 1207. 